\title{
Do different marketing practices pre-suppose different frames of reference? An exploratory study
}

\author{
Allam Abu Farha and Said Elbanna \\ Qatar University, Doha, Qatar
}

\begin{abstract}
Purpose - The role of managerial assumptions in the formulation of organizational strategies has been well recognized by previous studies, yet in marketing literature, the effect of such imperative on marketing practice choice tends to be ignored. Therefore, this paper aims to empirically investigate how management assumptions fit with the choice of marketing practices, and how such fit affects performance.

Design/methodology/approach - A model is developed and tested using survey methodology, and the data are analyzed using the partial least square (PLS) approach.

Findings - The results show that different marketing practices were coupled with different frames of reference, resulting in viable matching profiles. Research limitations/implications - Given the novelty of the approach adopted in this study, conclusions about association and not causation are drawn. In addition, the study is restricted to Qatar which may reduce the generalizability of its findings and conclusions.

Practical implications - The findings will help managers to examine carefully the internal logic of their marketing-related profiling, where coherent variables will enhance performance.

Originality/value - To one's knowledge, this paper reports a work in an area not previously researched. In addition, this study is one of the rare papers that examines unobserved heterogeneity using the PLS-structural equation modeling (SEM) in the field of marketing.
\end{abstract}

Keywords Performance, Emerging markets, Relationship marketing, Qatar, Marketing strategy, Management assumptions

Paper type Research paper

\section{Introduction}

The role of managerial assumptions in the formulation of organizational strategies has been well recognized in previous studies (Anderson and Paine, 1975; Hambrick and Mason, 1984; Child, 1997; Ivanova-Gongne, 2015). Although these studies provide important insights into the relationship between the characteristics of top managers and different organizational strategies at both the corporate and business levels (Auh and Menguc, 2005; Kaplan, 2011), the understanding of the possible match between managers' functional strategies (e.g. marketing practice) and their cognitive bases and interpretation of information remains limited (Gallen, 2006; Pels, 2010; Ryynänen et al., 2015).

Scholars have stressed that all managerial and strategic decisions are influenced by managerial conceptions (Lowe et al., 2016), yet the marketing literature tends to ignore - or, at best, apply sporadically - the effect of such an influence on the choice of marketing practice (Pels, 2010; Gallen, 2006; Raskovic, 2015). Accordingly, the first research question of this exploratory study is:

The current issue and full text archive of this journal is available on Emerald Insight at: www.emeraldinsight.com/0885-8624.htm

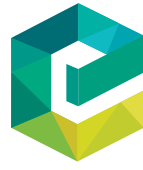

Journal of Business \& Industrial Marketing 33/3 (2018) 337-352

Emerald Publishing Limited [ISSN 0885-8624] [DOI 10.1108/JBIM-09-2016-0227]
RQ1. How can managers' assumptions about external conditions match their choice of contemporary marketing practices?

Complying with cognitive theory, which proposes that an alignment between top management and the organization's marketing choices leads to better performance (Gray, 2009; Walsh, 1995), the second research question is:

RQ1. What is the impact of different marketing practices on performance?

Despite repeated calls for studies to address these questions (Brodie et al., 2008), such studies are as yet few in number. More importantly, the few attempts that have been made to address this topic concentrate on a single aspect of marketing, such as market orientation or relationship marketing (Gummesson, 2004). However, different types of marketing practices that affect performance have rarely been tested (Coviello et al., 2006). We

(C) Allam Abu Farha and Said Elbanna. Published by Emerald Group Publishing Limited. This article is published under the Creative Commons Attribution (CC BY 4.0) licence. Anyone may reproduce, distribute, translate and create derivative work for this article (for both commercial and non-commercial purposes), subject to full attribution to the original publication and authors. The full terms of this licence may be seen at http://creativecommons.org/licences/by/4.0/legalcode.

Received 27 September 2016

Revised 11 March 2017

26 July 2017

7 September 2017

Accepted 7 September 2017 
believe that examining such relationships makes several important contributions. First, from a theoretical point of view, it enhances our understanding of the reasons for marketing diversity by indicating linkages between managerial assumptions and marketing practices, rather than relating this diversity to contingency factors. This is an issue that, to our knowledge, has not yet been tested. Second, it can make a significant contribution that furthers our understanding of the strategy formulation and competitive behavior of firms and provides a prior basis for understanding the consequences for the performance of each marketing practice.

Third, most previous studies were measured in developed economies, and their results varied by industry and setting, making it difficult to develop cogent theory and management practice in the field (Sweeney et al., 2011). Accordingly, this paper extends the work on this topic to a new setting to discover whether theories that predict well in one setting will be as effective in another (Berthon et al., 2002). Ongoing evidence suggests that companies in developed countries differ in their approaches and strategies from those in developing countries because of various variations in institutional development, market conditions, management practices and knowledge (Sheth, 2011). The importance of our study setting - namely, Qatar - is greater because of the organization of many sporting events on the global stage, such as the 2006 Asian Games, the 2015 World Men's Handball Championship and the upcoming FIFA World Cup of 2022. In addition, Qatar can be considered as representative of less researched Gulf Cooperation Council (GCC) countries (Elbanna, 2016). This may complement or improve our understanding of the predominant management and business models adopted from the "developed" world. In sum, with this setting choice, this study aims not only to replicate previous research in a new and less researched context but also to extend related research by testing a new relationship (Berthon et al., 2002). Therefore, our study is a replication with an extension.

Finally, this study is one of the rare papers that examines unobserved heterogeneity using the PLS-SEM in the field of marketing, which is considered a key area of concern according to several researchers (Sarstedt et al., 2011). From a managerial standpoint, our results identify a range of profiles that should help firms carefully examine the internal logic of their marketing-related profiling as well as manage their marketing practice accordingly.

The remaining parts in this study are organized as follows. First, previous literature on managerial assumptions and marketing practices is reviewed, and an appropriate classification of each variable in the theoretical framework is selected. Next, the paper presents its model and hypotheses. Then, the model is tested using a sample of 184 firms from Qatar. After discussing the results and implications of the partial least square (PLS) path analysis, the paper concludes by discussing its findings, implications for management and future avenues for research.

\section{Literature review}

The first two sections here review previously researched managerial assumptions and marketing practices. In particular, we justify our use of the frame of reference (FoR) framework and the transactional/relational marketing framework. The last two sections explore how FoR may impact marketing practice choices and how the latter affects performance.

\section{Managerial assumptions}

The importance of managerial assumptions in the formulation of organizational strategies and their role in explaining the diversity of strategic behavior has been identified by management researchers (Child, 1972; Hannan and Freeman; 1977; Hambrick and Mason, 1984; Kaplan, 2011). This line of work suggests that executive cognitions, values and perceptions all play a pivotal role in shaping organizational strategic choices (Kaplan, 2011). Researchers have found that managerial values and cognitive base influence their vision, selectivity and reading of the surrounding environment (Lowe et al., 2016; IvanovaGongne, 2015), thereby "directly entering in the strategic choice" (Hambrick and Mason, 1984, p. 195).

Several conceptualizations and terms in managerial assumptions have been suggested (Day and Nedungadi, 1994; Goodenough, 1971; Prahalad and Bettis, 1986; Shrivastava and Mitroff, 1983; Webster, 2005). For the purpose of the present study, we adopt the FoR typology proposed some time ago by Shrivastava and Mitroff (1983) as a determinant of managerial assumptions due to its rigorous basis and because its constructs have been clearly classified and operationalized (Pels et al., 2009).

Shrivastava and Mitroff (1983, p. 163) described FoR as "the fundamental assumptions on which organizational inquiry into problems is based upon." They included methodological, epistemic, ontological and ideological assumptions that enable organizational members to make consensual meaning out of social events (Shrivastava and Mitroff, 1983). In other words, FoR is the tool that enables organizations to make sense of events and pave the way for their "mindscapes" (Shrivastava and Mitroff, 1984). Organizational FoR is intended to be a collective term in the sense that it is shared by most of an organization's employees.

Shrivastava and Mitroff $(1983,1984)$ identified four types of organizational FoR - political FoR, entrepreneurial FoR, bureaucratic FoR and professional FoR (Table I) - based on six constructs:

1 Cognitive elements: the fundamental units of informationideas, notions, concepts and assumptions that are often taken for granted but cannot take place without personal inquiry or concept formation;

2 Cognitive operators: the methods by which vast amounts of data are obtained, ordered and rearranged to create meaning;

3 Reality tests: the processes that "anchor organizational inquiry and resulting actions in specific rules and regulations, personal values, social ideologies, customs, or scientific knowledge and thereby give them 'truth' or 'reality' status" (Shrivastava and Mitroff, 1983, p. 165);

4 Domain of inquiry: the scope and boundaries of the inquiry process that firms consider and address;

5 Degree of articulation: this is not an element of FoR, but rather pertains to the "degree to which the assumptions embodied in the other four elements have been articulated 
Table I Shrivastava and Mitroff's FoR typology

\begin{tabular}{|c|c|c|c|c|}
\hline Elements of FoR & Entrepreneurial FoR & Bureaucratic FoR & Professional FoR & Political FoR \\
\hline Cognitive elements & $\begin{array}{l}\text { Subjective information } \\
\text { Personal commitment }\end{array}$ & $\begin{array}{l}\text { Objective information } \\
\text { Firmal commitment }\end{array}$ & $\begin{array}{l}\text { Inter-subjective } \\
\text { information } \\
\text { Firmal commitment }\end{array}$ & $\begin{array}{l}\text { Subjective and objective } \\
\text { interest } \\
\text { Group or coalition } \\
\text { commitment }\end{array}$ \\
\hline Cognitive operators & $\begin{array}{l}\text { Judgment/Intuitive } \\
\text { analysis } \\
\text { Limited short term } \\
\text { problem formulation and } \\
\text { solution }\end{array}$ & $\begin{array}{l}\text { Computational analysis } \\
\text { Interpersonal inquiry }\end{array}$ & $\begin{array}{l}\text { Planning and } \\
\text { computational analysis } \\
\text { Long range problem } \\
\text { formulation and solution }\end{array}$ & $\begin{array}{l}\text { Bargaining and } \\
\text { negotiation } \\
\text { Inter-personal problem- } \\
\text { solving }\end{array}$ \\
\hline Reality tests & $\begin{array}{l}\text { Self-experience } \\
\text { Facts are what work or } \\
\text { get tasks accomplished }\end{array}$ & $\begin{array}{l}\text { Firmal rules procedures } \\
\text { procedural rigor }\end{array}$ & $\begin{array}{l}\text { Empirical, experimental } \\
\text { proofs methodological } \\
\text { rigor }\end{array}$ & $\begin{array}{l}\text { Popular wisdom social } \\
\text { and firmal norms }\end{array}$ \\
\hline Domain of inquiry & $\begin{array}{l}\text { Problem-specific changing } \\
\text { continuously }\end{array}$ & $\begin{array}{l}\text { Department-fixed and } \\
\text { well-drawn boundaries }\end{array}$ & Firmal-fixed boundaries & $\begin{array}{l}\text { Firmal and regional } \\
\text { changes with stakeholder } \\
\text { interests }\end{array}$ \\
\hline Degree of & Low & High & Medium & Low \\
\hline articulation & $\begin{array}{l}\text { Through gestures and } \\
\text { actions, non-verbal }\end{array}$ & $\begin{array}{l}\text { Through explicit } \\
\text { statement of assumptions, } \\
\text { rules }\end{array}$ & $\begin{array}{l}\text { Explicit in the knowledge } \\
\text { base used for decision- } \\
\text { making }\end{array}$ & $\begin{array}{l}\text { Through rhetoric and } \\
\text { metaphorical } \\
\text { communication }\end{array}$ \\
\hline Metaphors & Economic/militaristic & Economic/Social & Scientific & Political \\
\hline
\end{tabular}

and codified" (Shrivastava and Mitroff, 1983, p. 166); and

6 Metaphors: symbolic constructions of the firm's world in meaningful ways.

\section{Marketing practice}

The current literature proposes two major perspectives from which to understand the types of marketing practice. The proponents of the first adopts a dichotomous stand, where they distinguish among transactional and relational marketing, seeing them as sited at the opposite ends of a continuum (Håkansson and Snehota, 1989; Grönroos, 1991), with traditional goods-centric marketing at one end of the continuum and the emerging area of service-centered marketing at the other (Vargo and Lusch, 2004). The proponents of the second approach also conceptualize marketing practice along a continuum, but these adopt a more pluralistic stand through distinguishing between a range of marketing practices: transaction marketing (TM), database marketing (DM), interaction marketing (IM) and network marketing (NM) (Brodie et al., 2008); transactional exchanges, value-adding exchanges, and collaborative exchanges (Day, 2000); or transactional as well as narrow and broad relationship marketing (Sheth and Parvatiyar, 2000).

Although a dichotomous approach is useful for simplifying the relationships in the marketing field, thereby making it easy to understand the market dynamic, it does not capture the diversity of practices that can be found between the two poles (Coviello et al., 2002). Therefore, this paper adopts a pluralistic view and treats marketing practices as complementary rather than alternative (Arndt, 1979). Furthermore, we build on the framework of the contemporary marketing practice (CMP) group to demonstrate the variety of marketing practices. The work of the CMP group was chosen for many reasons. First, although it is the most developed, the work of this group "emphasizes both theoretical development (suggesting a typology) and empirical evidence, eliciting a taxonomy of marketing practices" (Pels, 2010, p. 135). Second, it is supported by extensive empirical work (Dadzie et al., 2008; Wagner, 2005).

Coviello et al. (1997) developed a classification scheme containing two main themes (relational exchange and management activities) corresponding to nine dimensions relating to firms' interaction with their markets. Guided by these indicators, they extended the two original types of marketing practice to four, as follows:

1 Transaction marketing: This type of marketing practice is a reflection of the marketing management school, where the focus is on "attracting and satisfying potential buyers by managing the elements in the marketing mix" (Coviello et al., 1997, p. 509). In this type of marketing, the seller is the active party, where communication is "to" rather than "with" the customer; when the goal is to obtain new customers, the transaction is at a short arm's length (Coviello et al., 2002).

2 Database marketing: Reflecting the tactical part of relationship marketing, the goal is to retain customers using technology-based tools. The seller is still the active party, and the communication is "to" the customer.

3 Interaction marketing: This type of relationship marketing seeks to develop interpersonal relationships with customers to create cooperative interactions for mutual benefit. It implies face-to-face interactions, which means that communication is "with" the customer and the goal is to retain current customers by creating a cooperative mutual benefit.

4 Network marketing: This approach carries the elements of IM, but seeks to form relationships between firms at different levels to permit the activities of multiple parties 
to be coordinated to build up the organization's position in a network of relationships.

\section{Effect of managerial assumptions on marketing practice} Although the marketing literature is silent about the effect of managerial assumptions on marketing decision-making processes (Pels et al., 2009), several authors have discussed the important role managerial assumptions play in such processes (Ivanova-Gongne, 2015), which highlights the significance of managerial assumptions in these processes (Gallen, 2006). For example, Day and Nedungadi (1994) suggested that it is not objective reality that drives managers' decisions, but their perception of their fluid competitive market arena. Deshpande and Webster (1989) suggested that organizational culture affects marketing; central to their argument is the organization's cognition. Krepapa and Berthon (2003) explored interpretative diversity and market learning by focusing on the way in which managers, for the sake of better understanding, construct a meaning for their surroundings.

On the empirical side, White et al. (2003) found that marketing managers' cognitive styles affect managers' interpretations of the market situation, which in turn affects the magnitude of their response. Similarly, Tollin and Jones's (2009) results indicated the existence of different and distinctive logics that dominate the marketing managers' decision-making processes. The central work that is consistent with this paper's purpose is that of Pels et al. (2009), who developed configurational profiles linking managerial assumptions and environmental actions to marketing practice.

The previous discussion has established the role of managerial assumptions in marketing decision-making processes and can be expressed by the FoR of the dominant coalition (White et al., 2003). Together, these suggest that a relationship between management perception and marketing practices should appear straightforward. Thomas and Ramaswamy (2005, p. 249) commented, "the logic of matching managers to strategy is intuitively appealing." There is an overwhelming anecdotal, theoretical and empirical evidence supporting this line of reasoning." Therefore, this paper proposes that a direct link between the management FoR and the marketing practice adopted is likely to exist. However, as this study is an exploratory study, we propose at this stage a parsimonious conceptual model.

\section{Linking marketing practice and performance}

Over the past three decades, marketing scholars have proposed two major perspectives to achieve better business performance (Coviello et al., 2006). One group posits a strong linkage between transactional marketing and business performance (Baker, 2014; Buzzell, 1999); its supporting argument depends on strong empirical evidence of ways to construct a welldesigned, coherent and fully integrated marketing strategy, leading to better financial performance.

However, many scholars with a background in service and industrial marketing argue that transactional marketing is inadequate, especially in service industries (Gummesson, 2004; Gronroos, 1990). Relational marketing, by linking customer retention and profit, can improve performance more effectively than transactional marketing can (Ballantyne et al.,
2002). Their rationale is that customers are willing to spend more money and engage more frequently with a firm that satisfies them.

Summarizing the discussion thus far, the marketing literature depicts data that support the proposition that firms with a welldesigned and executed marketing strategy (transactional or relational) will outperform their competitors (Low et al., 2007). However, as previously discussed, each team uses different performance measures to support its hypothesis. Thus, we propose testing this hypothesis using a variety of performance measures. This study focuses on three aspects of performance: sales growth, market share and profitability. This preference is widely reflected in the marketing literature (Coviello et al., 2006) and has been accepted by Vargo and Lusch (2004), despite "their emphasis on value-in-exchange rather than value-in-use" (Coviello et al., 2006, p. 42).

On the basis of the previous discussion, we would expect a relationship between an organization's FoR and marketing practice. Having said this and because this study is a theorygenerating one, we followed Lindgreen et al.'s study (2008) and proposed a parsimonious conceptual framework as presented in Figure 1. The proposed framework integrates the paper's three sets of variables: the organization's FoR, marketing practices and firm performance. In addition, it indicates the categories connected with each variable. The framework illustrates the thesis of this study - namely, that an organization's FoR affects the choice of marketing practice and, for each FoR type, there exists an ideal type of marketing practice. In addition, it assumes that different types of marketing practice will have an impact on different measures of firm performance. These two types of relationships are appealing if one considers the empirical and theoretical work that emphasizes the role played by managers' assumptions in determining the organization's strategic direction (Pels, 2010; White et al., 2003) and the effect that marketing practice has on firm performance (Baker, 2014; Buzzell, 1999).

\section{Methodology}

\section{Measures}

The conceptual model of this study was examined using a structured survey method. The research variables were based on earlier measurements obtained by the typologies' developers. The organizational FoR was developed on the basis of Shrivastava and Mitroff's (1983) study, for which 28 questions reflecting the four components of FoR were developed. Marketing practice was measured using the CMP standard questionnaire for marketing practices (The CMP group, Coviello et al., 1997), which contain a total of 36 questions. Each type of practice (TM, DM, IM and NM) was reflected in nine of these questions.

Finally, as firm performance is a multidimensional phenomenon and different sections of the firm may perform differently (Fadol et al., 2015), firm performance was measured using three aspects of performance representing financial and nonfinancial measures: sales growth, market share and profitability (Sweeney et al., 2011). Profitability and market performance are extensively recognized as being among the most important indicators of performance because these reflect measures used in the broader marketing literature (Coviello 
Figure 1 Conceptual framework

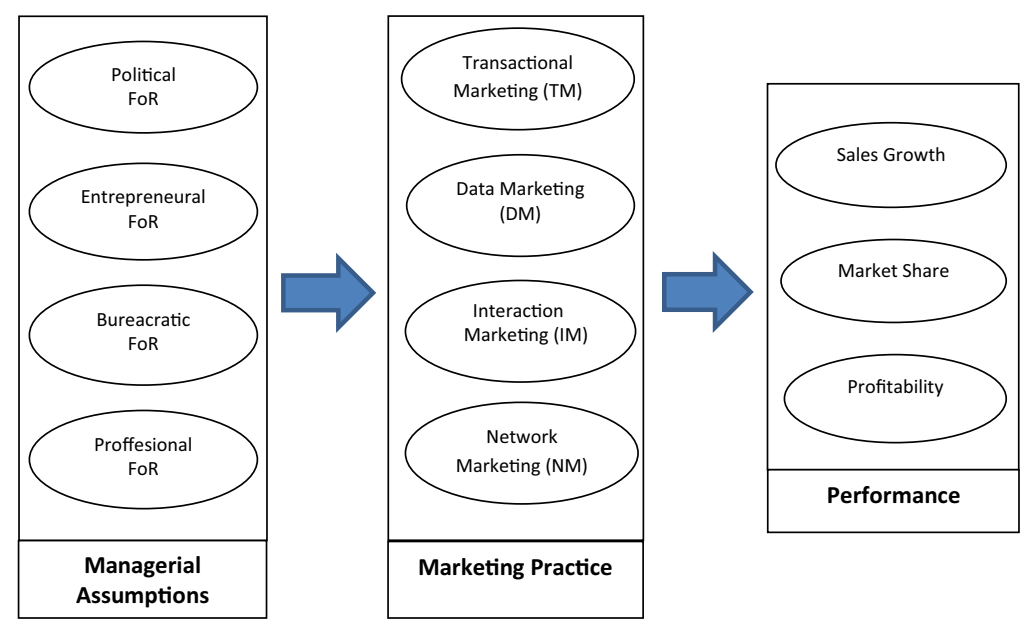

et al., 2006; Homburg and Pflesser, 2000). Furthermore, Vargo and Lusch (2004) considered these to be appropriate despite their stress on value-in-exchange instead of value-in-use as these provide information on the extent to which an organization achieves its marketing objectives. In addition, the use of these subjective indicators is more appropriate when a cross-industry setting is involved for a better comparison of performance (Matsuno et al., 2002) and their relevance, regardless of the level or type of strategy, is comprehensively investigated (Deshpandé and Farley, 1998). Finally, these subjective indicators are more appropriate as managers may be reluctant to disclose actual performance data (Coviello et al., 2006). In this regard, Dess and Robinson (1984) suggested that subjective data are strongly correlated with objective performance measures. The questionniare is presented in Appendix I.

\section{Data collection and sample}

The responses were collected from firms located in Qatar. The setting of Qatar can reflect the Gulf region's environmental conditions. Despite the increasing economic and political importance of this region, empirical data on its organizational and management practices are still lacking (Zahlan, 2016). Consequently, data that illuminate or attempt to analyze psychological and practical aspects of Qatari firms can be valuable (Fadol et al., 2015) and help test the generalizability of previous findings in a more global context (Elbanna, 2016). In addition, findings from different settings may influence CMPs in a different way than in developed countries (Dadzie et al., 2008), which can complement or improve the predominant management and business models from the "developed" world.

Data were gathered with the help of two experienced research assistants using the drop-off/pickup method of questionnaire administration (Tuncalp, 1999) between May and November 2015. The sampling population consisted of 245 private firms listed in the Qatar's Chamber of Commerce. Respondents' participation was voluntary and based on predetermined appointments. Of the targeted sample, 184 firms responded, yielding a response rate of 75 per cent, which is similar to related research using similar techniques of data collection in the GCC countries
(Elbanna, 2016). Following Elbanna's study (2015), we collected data from two respondents in 20 firms each to examine inter-rater reliability.

Table II introduces the demographics of the study sample. Of note, 20 per cent of participating organizations were less than two years old, whereas 50 per cent were established three to ten years ago and the remaining respondents were established 11 years ago or longer. With regard to market offers, 35 per cent offered services, around 5 per cent offered products and 60 per cent offered both. Of these organizations, 63 per cent were wholly domestically owned, whereas 12 per cent were completely foreign-owned and 25 per cent were jointly owned. With regard to the markets served, consumer markets accounted for 29 per cent and business markets accounted for 24 per cent. However, a majority (46 per cent) served both markets simultaneously.

In terms of the characteristics of the respondents, 86 per cent of them were male, and 65 per cent of them were between the ages of 30 and 50. Of those, 39 per cent were in upper management positions, whereas 35 and 26 per cent were in middle and functional management levels, respectively. As regard the category of position held, 28 per cent were in marketing, 36 per cent were engineers in management positions, 14 per cent were in finance and accounting, 12 per cent worked in human resource and other departments accounted for the final 10 per cent. This distribution was not unexpected because most Arab companies are small in size (Zahlan, 2016; Abdul-Muhmin, 2002) and cross-functional activities are common. We therefore expected that the respondents would be involved in, or at least have knowledge about, their company's marketing practices. Most of the respondents held a college degree ( 71 per cent) and 74 per cent of those who responded held six years of professional experience or longer.

The overall characteristics of the sampling pool obtained were consistent with previous international studies (Dadzie et al., 2008), and comparable in terms of statistical physiognomy with previous studies conducted in Arab countries (Elbanna, 2015; Abdul-Muhmin, 2002). 
Table II Company and individual characteristics

\begin{tabular}{|c|c|}
\hline Characteristics & $(\%)$ \\
\hline \multicolumn{2}{|l|}{ Position } \\
\hline Upper management & 38.7 \\
\hline Middle management & 34.9 \\
\hline Low management & 26.4 \\
\hline \multicolumn{2}{|l|}{ Specialty } \\
\hline Marketing and sales & 27.6 \\
\hline Finance and account & 14.2 \\
\hline HR & 12.2 \\
\hline Engineering & 36.3 \\
\hline Other & 9.7 \\
\hline \multicolumn{2}{|l|}{ Degree } \\
\hline High school & 5.5 \\
\hline Diploma & 3.6 \\
\hline College & 3.6 \\
\hline Bachelor & 64.4 \\
\hline Graduate degree & 22.9 \\
\hline \multicolumn{2}{|l|}{ Experience } \\
\hline Less than 3 years & 11.5 \\
\hline $3-5$ years & 16.6 \\
\hline $6-9$ years & 29.5 \\
\hline Over 10 years & 42.4 \\
\hline \multicolumn{2}{|l|}{ Age } \\
\hline $18-30$ & 26.9 \\
\hline $31-40$ & 42.4 \\
\hline $41-50$ & 22.8 \\
\hline Over 51 & 7.9 \\
\hline \multicolumn{2}{|l|}{ Gender } \\
\hline Male & 85.8 \\
\hline Female & 14.2 \\
\hline \multicolumn{2}{|l|}{ Market offers } \\
\hline Goods & 5.4 \\
\hline Services & 34.8 \\
\hline Both & 59.8 \\
\hline \multicolumn{2}{|l|}{ Age } \\
\hline Less than 2 years & 20.7 \\
\hline $3-5$ years & 27.2 \\
\hline $6-10$ years & 22.8 \\
\hline Older than 11 years & 29.3 \\
\hline \multicolumn{2}{|l|}{ Market served } \\
\hline Consumer & 28.7 \\
\hline Business & 24.6 \\
\hline Both & 46.7 \\
\hline \multicolumn{2}{|l|}{ Ownership } \\
\hline Locally owned & 62.7 \\
\hline Foreign owned & 12 \\
\hline Jointly owned & 25.3 \\
\hline
\end{tabular}

\section{Data analysis}

The present paper used the PLS approach. Adopting the PLS approach offers three advantages that coincide with the goals and characteristics of this study: it is a technique that is recommended for models that emphasize theory development
(Chin, 2010); it has an inherent ability to compute a cause-andeffect relationship model (Hair et al., 2011); and PLS puts minimum demand on measurement scales such as the sample size and conditions for normality (Henseler et al., 2009), making it particularly suitable for this study.

\section{Nonresponse bias, common method bias and recalling information bias}

The data on 89 per cent were collected from a single respondent in each firm, a limitation that may cause different types of bias, such as retrospective rationalization and incomplete recall. Following Elbanna's study (2015), we carried out several tests to ensure the absence of possible bias.

First, - in 20 firms (11 per cent), where we collected data from two respondents in each firm, we found that the data enjoy a strong level of inter-rater reliability. More specifically, 17 out of the 20 cases with two informants had a significant correlation at the 1 per cent level or better and the remaining three cases had a significant correlation at the 5 per cent level. The 20 firms had an average correlation coefficient of 0.65 . The second test implemented was Harman's single-factor test of common method bias. The results of exploratory factor analysis indicate that the variance in the data explained by the first factor is well below the cutoff point of 30 per cent, more specifically, 18 per cent. Hence, we expect very little common method variance. Both tests propose that any potential common method bias is small (Zhao et al., 2011), and we can safely claim that any relationship reported in this study indicates substantive rather than artificial effects.

\section{Data analysis}

Based on our sample of 184 firms, we tested the study model using Smart PLS version 2.0 (Ringle et al., 2005). Model estimation was performed on a two-tier procedure, as recommended by Henseler et al. (2009). First, we assessed the measurement model, which examines the relation between the constructs and its indicators. Then, we assessed the structural model, which shows the relationship between the constructs or latent variables.

\section{Measurement model results}

To evaluate the reflective measurements, the values of the indicator coefficients, composite reliability $(\rho \mathrm{c})$, Cronbach's $\alpha$ and the average variance extracted (AVE) for each construct (AVE) were used to examine the model's reliability and validity. Using the advice of Chin (2010) to accept items with a loading of over 0.50 if other items on the same construct reported high loadings, 21 items were deleted. This means that more than 50 per cent of the variance in the observed variables was shared with the construct.

Table III presents the model statistics of composite reliability $(\rho \mathrm{c})$, Cronbach's $\alpha$ and the AVE. The first column reports the results of the composite reliability $(\rho \mathrm{c})$ index, where all constructs exceeded the minimum value of 0.70 (Hair et al., 2006) with profitability showing the highest (0.95) and political FoR presenting the lowest (0.76). Composite reliability does not assume tau-equivalence, making it more suitable for PLS-SEM, which prioritizes indicators according to their individual reliability. However, 
Table III Psychometric properties of the structural model

\begin{tabular}{lccc}
\hline & Composite reliability $(\rho \mathbf{c})$ & Cronbach's $\alpha$ & AVE \\
\hline Political FOR & 0.762 & 0.540 & 0.517 \\
Bureaucratic FoR & 0.797 & 0.631 & 0.569 \\
Entrepreneurial FoR & 0.794 & 0.614 & 0.565 \\
Professional FoR & 0.877 & 0.835 & 0.546 \\
TM & 0.857 & 0.798 & 0.501 \\
DM & 0.841 & 0.764 & 0.517 \\
IM & 0.852 & 0.784 & 0.537 \\
NM & 0.876 & 0.836 & 0.502 \\
Sales growth & 0.929 & 0.847 & 0.867 \\
Market share & 0.93 & 0.849 & 0.869 \\
Profitability & 0.945 & 0.884 & 0.896 \\
\hline
\end{tabular}

this paper examined Cronbach's $\alpha$ as a matter of convention without giving it too much importance because it gives the lower bound estimates of reliability and assumes a tauequivalency among the measures with its assumption that all indicators are equally weighted (Chin, 2010). All the constructs except three (political "0.54," entrepreneur “ 0.61 " and bureaucratic " 0.63 ") reported a value of over 0.70 . The moderate value for these three constructs is due either to the small sample size or to the previously mentioned limitation of Cronbach's $\alpha$. These results show that the model passed the construct reliability test, that this reliability provided evidence of unidimensionality, and that the constructs were suitable for further analysis (Wilson, 2010).

In evaluating the model's convergent validity, Fornell and Larcker (1981) advised using the AVE to evaluate the model's convergent validity. This measure for the proposed model ranged from 0.50 to 0.90 , as shown in the last column of Table III, which is above the cutoff point of 0.50 . This means that the latent variables were able on average to explain more than half of the variance of the model's indicators, demonstrating sufficient convergent validity.

To confirm that discriminant validity was established, Table IV shows that the AVE square root (on the diagonal line) is higher than all correlations below, which means that each latent variable has more variance with its indicator than with any other latent variable (Henseler et al., 2009). In sum, the results show satisfactory discriminant validity on the construct and on the item level.

\section{Structural model results}

The reliable and valid outer model allows us to evaluate the inner path model estimates. The psychometric properties of the structural model are shown in Table $\mathrm{V}$, which includes the coefficient of determination $\left(R^{2}\right)$, Stone-Geisser's $\left(Q^{2}\right)$ and communality for all constructs.

The $R^{2}$, which indicates how much of the endogenous variable is explained by the exogenous variables, reported scores between 0.27 and 0.37 . These scores are considered moderate scores (Chin, 2010) and are acceptable in value, according to Henseler et al. (2009). The $Q^{2}$, which shows the model's capacity to predict, reported values over zero, ranging from 0.11 to 0.23 , which means that these have great predictive relevance (Henseler et al., 2009). The last column presents the communality values, which show how much variance each construct shares with all the other variables included in the model. All the constructs reported communality above the critical point of 0.5 (Hair et al., 2006), which indicates that these have sufficient explanations.

Table VI reports the effect size, $F^{2}$, and the variance inflation factor (VIF). $F^{2}$ is calculated as the increase in $R^{2}$ relative to the proportion of variance of the endogenous latent variable that remains unexplained (Chin, 2010). All the values of the model are above the critical point of zero (Henseler et al., 2009), and range from small to large, according to Cohen (1988), who considered the values $0.02,0.15$ and 0.35 to have small, medium, and large effects, respectively. The third column shows that the VIF values are far below 10, indicating the absence of multicollinearity.

The empirical results shown in Figure 2 indicate all the significant paths after running the bootstrap 5,000 times and deleting all the nonsignificant relationships.

The proposed model's significant path coefficient and moderate $R^{2}, Q^{2}$ and $F^{2}$ indicate the strong explanatory power, high predictive relevance and applicability of the chosen variables; therefore, it is appropriate now to provide an analysis of the model's findings.

\section{Analysis of heterogeneity in the sample}

Henseler et al. (2009) recommended testing for and dealing with unobserved heterogeneity, because if not carefully taken into account, it may create a misleading interpretation. The finite mixture partial least squares (FIMIX)-PLS method has been described as one of the best-known approaches for

Table IV Latent variable correlations

\begin{tabular}{|c|c|c|c|c|c|c|c|c|c|c|c|}
\hline & Political FOR & Bureauc FoR & Entrepren FoR & Profess FoR & TM & DM & $\mathrm{IM}$ & NM & Sales growth & Market share & Profitability \\
\hline Political FOR & 0.719 & & & & & & & & & & \\
\hline Bureaucratic FoR & 0.354 & 0.754 & & & & & & & & & \\
\hline Entrepren FoR & -0.011 & -0.269 & 0.752 & & & & & & & & \\
\hline Professional FoR & 0.095 & 0.63 & -0.133 & 0.739 & & & & & & & \\
\hline TM & 0.479 & 0.432 & -0.225 & 0.169 & 0.710 & & & & & & \\
\hline DM & 0.314 & 0.339 & 0.06 & 0.492 & 0.337 & 0.720 & & & & & \\
\hline IM & -0.001 & -0.155 & 0.541 & 0.056 & -0.111 & 0.221 & 0.733 & & & & \\
\hline NM & 0.142 & 0.185 & 0.235 & 0.397 & -0.023 & 0.494 & 0.541 & 0.709 & & & \\
\hline Sales growth & 0.209 & 0.075 & 0.194 & 0.025 & 0.503 & 0.215 & 0.290 & 0.148 & 0.931 & & \\
\hline Market share & 0.09 & 0.038 & 0.227 & 0.135 & 0.158 & 0.304 & 0.475 & 0.378 & 0.664 & 0.932 & \\
\hline Profitability & 0.144 & 0.011 & 0.258 & 0.091 & 0.242 & 0.283 & 0.433 & 0.345 & 0.752 & 0.851 & 0.950 \\
\hline
\end{tabular}


Table V Psychometric properties of the structural model

\begin{tabular}{llcc}
\hline & $R^{2}$ & $Q^{2}$ & Communality \\
\hline Political FOR & & & 0.041 \\
Bureaucratic FoR & & & 0.154 \\
Entrepreneurial FoR & & & 0.145 \\
Professional FoR & & & 0.356 \\
TM & 0.308 & 0.144 & 0.291 \\
DM & 0.338 & 0.164 & 0.272 \\
IM & 0.293 & 0.154 & 0.3 \\
NM & 0.242 & 0.114 & 0.323 \\
Sales growth & 0.375 & 0.319 & 0.515 \\
Market share & 0.27 & 0.228 & 0.518 \\
Profitability & 0.273 & 0.236 & 0.586 \\
\hline
\end{tabular}

Table VI Effect size $\left(F^{2}\right)$ and VIF results

\begin{tabular}{lcll}
\hline & $\boldsymbol{F}^{2}$ & Effect size & VIF \\
\hline Political $\rightarrow$ TM & 0.176 & Medium & 1.143 \\
Political $\rightarrow$ DM & 0.121 & Small & 1.019 \\
Bureaucratic $\rightarrow$ TM & 0.114 & Small & 1.143 \\
Entrepreneurial $\rightarrow$ DM & 0.036 & Small & 1.029 \\
Entrepreneurial $\rightarrow$ IM & 0.414 & Large & 1 \\
Entrepreneurial $\rightarrow$ NM & 0.111 & Small & 1.018 \\
Professional $\rightarrow$ DM & 0.438 & Large & 1.025 \\
Professional $\rightarrow$ NM & 0.246 & Medium & 1.018 \\
TM $\rightarrow$ Sales growth & 0.465 & Large & 1.013 \\
TM $\rightarrow$ Profitability & 0.117 & Small & 1.013 \\
TM $\rightarrow$ Market share & 0.062 & Small & 1.013 \\
IM $\rightarrow$ Sales growth & 0.194 & Medium & 1.013 \\
IM $\rightarrow$ Market share & 0.336 & Large & 1.013 \\
IM $\rightarrow$ Profitability & 0.295 & Medium & 1.013 \\
\hline
\end{tabular}

uncovering unobserved heterogeneity in PLS path modeling (Sarstedt et al., 2011). FIMIX-PLS simultaneously estimates the inner model parameters and ascertains the heterogeneity of the data structure by calculating the probability of the observations' segment membership so that they fit into a predetermined number of segments (Hahn et al., 2002).

This test is an iterative process; therefore, the process started by calculating the solutions for the numbers of segments $(\mathrm{K})$, we did calculate from $\mathrm{K}=2$ to $\mathrm{K}=6$. Table VII demonstrates the goodness of fit for the different solutions. Sarstedt et al. (2011) recommended the use of a combination of Akaike's information criterion (AIC3), consistent AIC (CAIC) and normed entropy (EN) as the most adequate. A quick comparison of those indicators for each segment classification suggested that the three segment solution was the most appropriate choice, and with it we found the minimum values for CAIC and AIC3 for K3, which provide strong support for the adequacy of this segment solution (Sarstedt et al., 2011). In addition, $\mathrm{K} 3$ has the highest $\mathrm{EN}$ value (above the cutoff point of 0.5 ) which indicates that the segments are well separated (Ringle et al., 2010).

The results for the segment-specific PLS path-modeling results are presented in Table VIII[AQ9]. Their psychometric properties confirm that all the relevant criteria for the measurement and structural model evaluation (Henseler et al., 2009) were satisfactorily met. The satisfactory values of the composite reliability ( $\rho$ c), Cronbach's $\alpha$ and AVE showed that the model reliability and validity criteria were met. In regard to the structural model, the $R^{2}$ values for the four marketing practices and performance measures are more moderate. The bootstrapping results reveal that almost all the significant path coefficients in the original model are also statistically significant in the three segments.

Figure 2 Empirical results

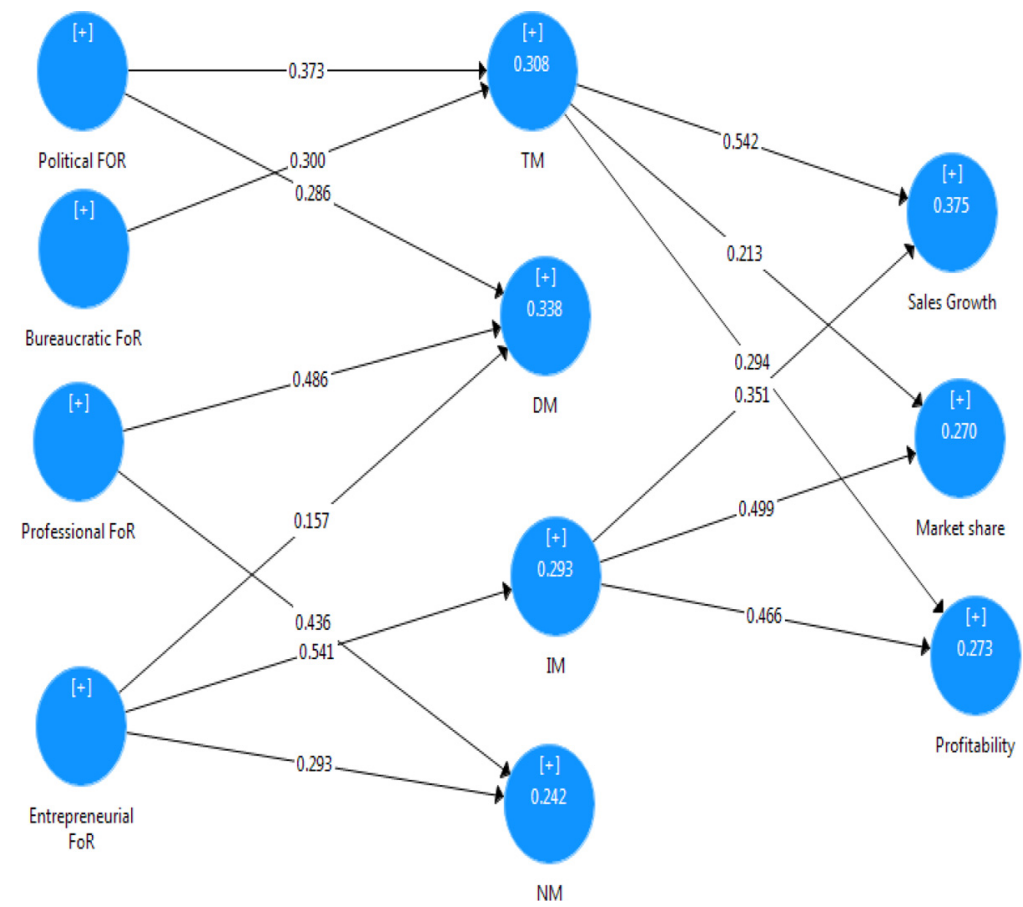


Table VII Goodness of fit and percentage of allocation by number of segments

\begin{tabular}{lcccccc}
\hline & $\mathrm{K}=1$ & $\mathrm{~K}=2$ & $\mathrm{~K}=\mathbf{3}$ & $\mathrm{K}=4$ & $\mathrm{~K}=5$ & $\mathrm{~K}=\mathbf{6}$ \\
\hline AIC3 (modified AIC with Factor 3) & $3,256.69$ & $3,160.09$ & $3,011.36$ & $3,073.22$ & $3,057.76$ \\
CAIC (consistent AIC) & $3,324.21$ & $3,298.33$ & $3,100.33$ & $3,352.92$ & $3,408.19$ \\
EN (entropy statistic [Normed]) & NA & 0.759 & 0.875 & 0.818 & $3,462.55$ \\
\hline
\end{tabular}

Table VIII FIMIX-PLS results for the three-segment solutions

\begin{tabular}{|c|c|c|c|}
\hline & Segment 1 & Segment 2 & Segment 3 \\
\hline \multicolumn{4}{|l|}{ Path coefficient } \\
\hline Bureaucratic FoR $\rightarrow$ TM & -0.185 & $0.580^{*}$ & $0.583^{*}$ \\
\hline Entrepreneurial FoR $\rightarrow$ DM & 0.217 & 0.136 & 0.018 \\
\hline Entrepreneurial FoR $\rightarrow \mathrm{IM}$ & $0.396^{*}$ & $0.650^{*}$ & $0.505^{*}$ \\
\hline Entrepreneurial FoR $\rightarrow$ NM & 0.111 & $0.368^{*}$ & $0.378^{* *}$ \\
\hline Political FOR $\rightarrow$ DM & -0.053 & 0.261 & $0.553^{*}$ \\
\hline Political FOR $\rightarrow$ TM & $0.494^{*}$ & 0.101 & 0.200 \\
\hline Professional FoR $\rightarrow$ DM & $0.421 *$ & $0.529^{*}$ & $0.254^{* *}$ \\
\hline Professional FoR $\rightarrow$ NM & $0.628^{*}$ & 0.460 * & 0.314 \\
\hline IM $\rightarrow$ Profitability & $0.304^{* *}$ & $0.458^{*}$ & $0.583^{*}$ \\
\hline IM $\rightarrow$ Sales growth & 0.123 & $0.432^{*}$ & $0.373^{*}$ \\
\hline IM $\rightarrow$ Market share & 0.461 * & $0.412^{*}$ & $0.605^{*}$ \\
\hline TM $\rightarrow$ Profitability & $0.309 * *$ & 0.216 & $0.454^{*}$ \\
\hline $\mathrm{TM} \rightarrow$ Market share & 0.168 & 0.202 & $0.351 *$ \\
\hline $\mathrm{TM} \rightarrow$ Sales growth & $0.637^{*}$ & $0.406^{*}$ & $0.659^{*}$ \\
\hline \multicolumn{4}{|l|}{$R^{2}$} \\
\hline TM & 0.334 & 0.412 & 0.462 \\
\hline DM & 0.323 & 0.403 & 0.525 \\
\hline IM & 0.157 & 0.422 & 0.255 \\
\hline NM & 0.457 & 0.193 & 0.191 \\
\hline Sales growth & 0.428 & 0.284 & 0.561 \\
\hline Market share & 0.248 & 0.178 & 0.478 \\
\hline Profitability & 0.198 & 0.218 & 0.532 \\
\hline \multicolumn{4}{|l|}{ AVE } \\
\hline Political FOR & 0.530 & 0.476 & 0.487 \\
\hline Bureaucratic FoR & 0.369 & 0.632 & 0.583 \\
\hline Professional FoR & 0.627 & 0.467 & 0.543 \\
\hline Entrepreneurial FoR & 0.496 & 0.569 & 0.609 \\
\hline $\mathrm{TM}$ & 0.475 & 0.430 & 0.611 \\
\hline DM & 0.473 & 0.496 & 0.591 \\
\hline IM & 0.472 & 0.504 & 0.649 \\
\hline NM & 0.525 & 0.467 & 0.545 \\
\hline Sales growth & 0.841 & 0.850 & 0.908 \\
\hline Market share & 0.877 & 0.813 & 0.927 \\
\hline Profitability & 0.836 & 0.913 & 0.913 \\
\hline \multicolumn{4}{|l|}{$C R$} \\
\hline Political FOR & 0.769 & 0.730 & 0.731 \\
\hline Bureaucratic FoR & 0.535 & 0.836 & 0.807 \\
\hline Professional FoR & 0.908 & 0.836 & 0.876 \\
\hline Entrepreneurial FoR & 0.733 & 0.797 & 0.819 \\
\hline TM & 0.835 & 0.818 & 0.902 \\
\hline DM & 0.815 & 0.826 & 0.878 \\
\hline IM & 0.816 & 0.835 & 0.902 \\
\hline NM & 0.886 & 0.859 & 0.893 \\
\hline Sales growth & 0.914 & 0.919 & 0.952 \\
\hline Market share & 0.934 & 0.897 & 0.962 \\
\hline Profitability & 0.911 & 0.954 & 0.955 \\
\hline
\end{tabular}

Comparing the outcomes of the original model (Figure 2) with those found from the FIMIX 3 segments (Table VIII), one can find similarities and some substantial differences in the strength of the path coefficients and in some cases small sign changes. In the first segment, 9 out of 14 paths were found to be significant, and close in strength to the original model, with the TM effect on sales growth being the strongest $(0.634)$. However, two paths did change their signs: bureaucratic effect on TM and political effect on DM. In the second and third segments, there were no sign changes, and more significant paths were found that were even closer to the original sample in their strength. Nevertheless, the finding from the FIMIX-PLS analysis reveals that the $R^{2}$ values, as well as the path coefficients, and CR of the model differ from one segment to another, but these look more persuasive. Most of the endogenous constructs had increased overall $R^{2}$ values, ranging between 0.157 (IM) and 0.525 (DM). This indicates that the organizations within the three groups do behave differently but most of the relationships found from the original model stay valid for the three models.

Taken these findings, an examination of whether the differences in the results between the three segments were significant can be taken. Chin (2000) recommended running a multigroup analysis (MGA) to demonstrate such a calculation. Table IX introduces the test results from comparing the different samples. As can be seen, in the 12 relationships, five differences were found to be significant, which establishes the existence of heterogeneity in the original sample. In addition, the absence of significance in the outcomes of the complementary analyses done for on the demographic variables confirms that the heterogeneity reflects the effect of manager's different perceptions on the choice of marketing practice.

\section{Findings}

The importance of managerial assumptions in formulating organizational strategies behavior has been identified by management researchers (Özleblebici et al., 2015; Child, 1972). However, their effect on directing marketing practices has not been identified. The results obtained from the PLS path in this study indicates the existence of a certain degree of internal coherence and consistency between the two variables (FoR and MP) and shows the effect that managerial FoR has on the choice of marketing practice. Several relationships were found between the two variables.

The first relationship, managers with political FoR, was found to be associated with transactional marketing practice (TM and DM). This significant relationship is expected if one considers the fact that political FoR in the Arab world is found in manager-centric organizations where decisions are based more on the managers' beliefs than the requirements of the outside world (Souiden, 2002). Such characteristics go along with the TM practice that focuses on creating discrete armslength transactions and impersonal practice (Coviello et al., 


\begin{tabular}{lccc}
\hline & Path diff $((1.0)-(2.0))$ & $\begin{array}{c}t \text {-value } \\
((1.0)-(3.0))\end{array}$ & $\begin{array}{c}t \text {-value }((1.0)-(2.0)) \\
((1.0)-(3.0))\end{array}$ \\
\hline Bureaucratic FoR -> TM & 0.765 & 0.769 & $4.532^{*}$ \\
Entrepreneurial FoR -> DM & 0.081 & 0.199 & 0.464 \\
Entrepreneurial FoR -> IM & 0.254 & 0.109 & 1.851 \\
Entrepreneurial FoR -> NM & 0.258 & 0.268 & 1.683 \\
Political FOR -> DM & 0.314 & 0.606 & 1.477 \\
Political FOR -> TM & 0.393 & 0.294 & $2.677^{*}$ \\
Professional FoR -> DM & 0.108 & 0.168 & 0.583 \\
Professional FoR -> NM & 0.168 & 0.314 & 1.298 \\
TM -> Market share & 0.033 & 0.183 & 0.192 \\
TM -> Profitability & 0.094 & 0.145 & 0.496 \\
TM -> Sales growth & 0.231 & 0.023 & 1.671 \\
IM -> Market share & 0.049 & 0.144 & 0.335 \\
IM -> Profitability & 0.153 & 0.279 & 0.911 \\
IM -> Sales growth & 0.309 & 0.249 & $0.881^{*}$ \\
\hline
\end{tabular}

1997). In addition, the political FoR manager's focus is on constantly following the same strategy if it meets with initial success (Schneider and Shrivastaval, 1988) and matches the focus of TM practice of standardizing the message sent to the mass market. Finally, political managers' continued commitment to their coalition's wealth, along with that of their own, interacts with the TM orientation for growth and expansion (Brodie et al., 1997).

The second positive relationship was found between bureaucratic FoR and TM. The nature of bureaucratic FoR managers is to commit to the organization's rules, which turns them into "risk avoiders" (Shrivastava and Mitroff, 1983), thereby pursuing more conservative strategies (Miller and Toulouse, 1982), such as TM practice. In addition, research has found that traditional Arab managers consider market research and other marketing tools as alien to direct selling and more in light of luxury expenses that are not needed, as more traditional marketing methods deliver better results (Souiden, 2002).

The third positive relationship was found between entrepreneurs' FoR and relationship marketing practices (DM, IM and NM) with the strongest path to IM. As organizations with entrepreneurial FoR have a broad view and look to innovate, they tend to eschew formal sources; rather, they prefer informal sources of information that come from internal and external data (Shrivastava and Mitroff, 1983). Such managers harmonize with RM, who seek to build long-term relationships with each customer, to better understand their needs and deliver faster, more innovative methods than a competitor can (Gummesson, 2002; Grönroos, 1995).

The last match shows a relationship between professional FoR and RM practices. This may be an interesting finding because organizations with such managers depend on models, scientific rigor and empiricism; therefore, they may prefer TM (Pels, 2010). However, if we consider the long-term perspective of the professionals' FoR, their broad domain of inquiry and their tendency to use different sources of information would lead one to reasonably expect such a finding. Previous research has shown that establishing more open relationships with customers and other stakeholders is a major strategy for recreating stability, thereby opening up value-creating opportunities in new ways (Day, 2000; Gummesson, 2002). Such a belief is becoming an accepted model and idea for professional organizations, which consequently try to implement it and make it a strategic choice.

As for the second focus of this paper, we find an interesting result concerning the marketing practice-performance relationship. Of all the practices inspected, only TM and IM were found to affect performance. Both practices positively affected the performance measures, whereas TM was more closely related to sales growth. This is consistent with Coviello et al.'s $(1997,2000)$ suggestion that this type of practice is managed by the seller and seeks growth opportunities. In contrast, IM was more closely associated with market share outcome, which is consistent with the face-to-face, impersonal nature of the practice that yields higher customer retention, thereby increasing the market share of a firm.

Surprisingly, the other relational practices (DM and NM) had no effect on a firm's performance. One reason for this may be the relatively low implementation levels, or perhaps such "practices are too new and/or resource intensive to have an impact on performance" (Coviello et al., 2006). Although these results agree with some previous research findings - namely, that relationship marketing practices are not a significant predictor of performance (Coviello et al., 2006) - these do contradict the emerging services-dominant logic suggested by Vargo and Lusch (2004), which argues that shifting from the $4 \mathrm{P}$ strategies to competing on the basis of service plays a crucial part in improving performance (Gummesson, 2004). These results indicate that transactional and interactive marketing practices together form the backbone of practice and that transactional marketing is still relevant to a firm's profitability. In other words, it is the efficiency and frequency of a practice, not the type of practice that can maximize a firm's performance.

\section{Discussion}

Previous research has argued the need to examine the relationship between managerial assumptions and strategic decisions (Pels et al., 2009). In addition, a few studies have investigated how marketing practice choice affects 
organizational outcomes (Brodie et al., 2008; Coviello et al., 2006). In response to that need, this study has sought to provide irrefutable, empirical support by showing how organizational FoR can affect the dominant marketing practice choice adopted and, in turn, how such choice affects firm performance.

The findings of this study show that the organizational FoR and marketing practice choice are inter-related, indicating that managers choose a marketing practice on the basis of their perceptions and readings of the environment. The results support the relevance of management beliefs in marketing decisions and endorse the idea that diverse strategic decisions are attributed to the different models used by managers to demonstrate the competitive advantages of their businesses, the types of representations they adopt (Shrivastava and Mitroff, 1984), and the type of information they rely on to assess their competitive advantages (Pels, 2010). The findings also imply that marketing practice diversity is more likely to be attributed to different managerial perceptions than to contingency factors.

In addition, this study has found two ways to enhance performance - namely, transactional marketing and interactive marketing - which conflicts with the increased attention given to new forms of marketing practice, such as NM (Vargo and Lusch, 2004). Indeed, the findings of this study indicate that such forms of practice have no direct impact or influence on performance. This initiates dialogue on the co-existence of product- and service-centered logics in most markets (Day et al., 2004), whereas "firms focusing on relational buyers only, as opposed to transactional buyers, would be disadvantageous" (Reinartz and Kumar, 2000, p. 26). This study proposes that, as long as fundamental organizational goals are seeking sales growth and profitability, transactional marketing would be a form of marketing practiced to attract new customers.

The framework presented in this paper makes several contributions to enrich the management literature. First, the findings contribute to an enhanced understanding of strategic leadership theory. Unlike previous approaches, which focus on specific managerial attributes that are associated with decisionmaking processes, these results focus on subjective cognitive processes. These processes underpin the identification of organizations' strategic behavior to highlight the importance of their ideologies and subjective interpretation for organizational decision-making processes. In other words, this paper explicitly shows that the FoR can explain why different assumptions exist; it further shows the vital role the FoR performs in the decision-making process. Second, companies responded to different profiles of marketing practice and managerial FoR, which supports the existence of the two imperatives and their underlying constructs, thereby supporting their adoption. Third, the results show that it is not the contingency factors that influence the marketing choice; instead, the choice of marketing is based on internal factors. The differences within the company itself cause such diversity. Next, this paper's results suggest that transactional and interactive marketing practices are, together, the backbone of practice and that transactional marketing is still relevant to a firm's profitability. In other words, it is the combination of how often and how well an organization carries out a practice, not the type of practice that will maximize organizational performance. Finally, from a methodological perspective, this study investigated the unobserved heterogeneity in some Arabic firms using MGA analysis and identified three types of groups. This issue is a critical area of concern that has rarely been addressed in previous studies (Sarstedt et al., 2011; Henseler et al., 2009).

\section{Managerial implications}

From a managerial standpoint, the results obtained in the present research offer a number of implications for those managers who seek to recognize an opportunity to generate a competitive advantage by developing alternative or additional marketing practices. First, the results suggest that different marketing practices are linked to different frames of reference. Hence, managers should carefully examine the internal logic of their marketing-related profiling and manage their marketing practices accordingly. That is, if managers acknowledge how their FoR impacted the adoption of a certain marketing practice, it could increase the effectiveness and efficiency of their marketing decision-making process. In this regard, White (2003) suggested that building up effective firms not only involves assuming or developing new resources and techniques but also demands an understanding of the way in which these forces relate to adopt practices that may be valid for ensuring the survival of that organization.

Second, the findings suggest that viable marketing practices are contingent on managerial frames of reference. Consequently, a better understanding of the right match will also provide managers with a basis for better recommendations for improving marketing decision-making processes. Lindgreen et al. (2008), for example, discussed that the development of marketing practices involves not only adopting or acquiring new resources and techniques but also an underlying understanding of how to enthuse, manage and motivate those within the organization to work both differently and more effectively.

Third, if managers became tacitly aware of the fit of marketing practices in the organization FoR, they would better understand their rival's practices and respond in a far more effective manner, which would suit their own combination rather than becoming merely reactionary. Pels (2010) found that the acknowledgment of how marketing practices interrelate to other imperatives was useful for managers' better understanding of their competitors related to their markets. In addition, this study finds that managers should be cautious when deciding which marketing practices to adopt because part of the international benchmarks in developed countries might be irrelevant to their perception and would not fit in their local markets.

Finally, our results suggest that improving performance is not tied to the use of relational marketing practices and that transactional marketing is still relevant to a firm's profitability. As we have noted, organizational performance is not maximized by the category of practice chosen, but rather by the frequency and quality of its implementation.

\section{Limitations and future research}

This study was exploratory in nature; thus, several limitations should be highlighted. First, given the novelty of the approach adopted in this study, we drew conclusions about association, not causation. Second, this paper was linked to theorizing 
(Weick, 1995) and, by extension, contributed to theory building rather than theory testing; therefore, we did not suggest any hypotheses. Third, the study was restricted to Qatar and to a small sample, which may reduce the generalizability of its findings and conclusions. This study also did not assess the quality of marketing practice; future research might use a management perspective in assessing the effectiveness and perceived value of specific practices.

With these findings and the limitations highlighted, we believe that this study opens up avenues for potential future research. Although our study was exploratory in nature, when checking whether relationships between organization FoR and marketing practice exist or not, any future work might want to explore in detail why such relationships exist. This can be done for the whole model, including all relationships, or by taking one cluster and investigating its occurrence, examining the dynamics that affect its relationships. Furthermore, this study included firms from a range of industries and offerings. An interesting branch of research development may be to conduct a study within the same industry. Moreover, this study was restricted to the Qatari market; a replication of this revision to other countries and/or markets, along with a comparison of results, would increase the validity and application of these findings and allow for greater insights into its generalizability to be shared. Future studies can also build on our results to develop and examine certain hypotheses that were beyond the objectives and the capacity of this study. Finally, although testing the effectiveness of marketing practice on performance was a valid step, checking other antecedents of performance, such as customer retention, would yield even greater insights still.

\section{References}

Abdul-Muhmin, A.G. (2002), "Effects of suppliers' marketing program variables on industrial buyers' relationship satisfaction and commitment", fournal of Business $\mathcal{E}$ Industrial Marketing, Vol. 17 No. 7, pp. 637-651.

Anderson, C. and Paine, F. (1975), "Managerial perceptions and strategic behavior", Academy of Management fournal, Vol. 18 No. 4, pp. 811-823.

Arndt, J. (1979), "Toward a concept of domesticated markets", fournal of Marketing, Vol. 43 No. 4, pp. 69-75.

Auh, S. and Menguc, B. (2005), "The influence of top management team functional diversity on strategic orientations: the moderating role of environmental turbulence and inter-functional coordination", International Fournal of Research in Marketing, Vol. 22 No. 3, pp. 333-350.

Baker, M. (2014), Marketing Strategy and Management, Palgrave Macmillan, Basingstoke.

Ballantyne, D., Christopher, M. and Payne, A. (2002), Relationship Marketing, Creating Stakeholder Value, Butterworth-Heinemann, Oxford.

Berthon, P., Pitt, L., Ewing, M. and Carr, C.L. (2002), "Potential research space in MIS: a framework for envisioning and evaluating research replication, extension, and generation", Information Systems Research, Vol. 13 No. 4, pp. 416-427.

Brodie, R., Coviello, N. and Winklhofer, H. (2008), "Contemporary marketing practices research program: a review of the first decade", fournal of Buisness and Industrial Marketing, Vol. 23 No. 2, pp. 84-94.
Brodie, R., Coviello, N., Brookes, R. and Little, V. (1997), "Towards a paradigm shift in marketing? An examination of current marketing practices", fournal of Marketing, Vol. 13 No. 5, pp. 383-406.

Buzzell, R. (1999), "Market functions and market evolution", Fournal of Marketing, Vol. 63, pp. 61-63.

Child, J. (1972), "Organizational structure, environment and performance: the role of strategic choice", Sociology, Vol. 6 No. 1, pp. 1-22.

Child, J. (1997), "Strategic choice in the analysis of action, structure, organizations and environment: retrospect and prospect”, Organization Studies, Vol. 18 No. 1, pp. 43-76.

Chin, W. (2010), "How to write up and report PLS analyses", in Vinzi, V., Chin, W., Henseler, J. and Wang, H. (Eds), Handbook of Partial Least Squares: Concepts, Methods and Applications in Marketing and Related Fields, 1st ed., Springer, Berlin.

Cohen, J. (1988), Statistical Power Analysis for the Social Sciences, Lawrence Erlbaum Associates, Hillsdale, NJ.

Coviello, N., Brodie, R. and Munro, H. (1997), "Understanding contemporary marketing: development of a classification scheme", fournal of Marketing Management, Vol. 13 No. 6, pp. 501-522.

Coviello, N., Winklhofer, H. and Hamilton, K. (2006), "Marketing practices and performance of small service firms: an examination in the tourism accommodation sector", Fournal of Service Research, Vol. 9 No. 1, pp. 38-58.

Coviello, N., Brodie, R., Danaher, P. and Johnston, W. (2002), "How firms relate to their markets: an empirical examination of contemporary marketing practices", fournal of Marketing, Vol. 66 No. 3, pp. 33-46.

Dadzie, K., Johnston, W. and Pels, J. (2008), "Business-tobusiness marketing practices in West Africa, Argentina and the United States", Fournal of Business \& Industrial Marketing, Vol. 23 No. 2, pp. 115-123.

Day, G. (2000), "Managing market relationships", fournal of the Academy of Marketing Science, Vol. 28 No. 1, pp. 24-30.

Day, G. and Nedungadi, P. (1994), "Managerial representations of competitive advantage", Fournal of Marketing, Vol. 58 No. 2, pp. 31-44.

Day, G.S., Deighton, J., Narayandas, D., Gummesson, E., Hunt, S. D., Prahalad, C., Rust, R. T. and Shugan, S. M. (2004), "Invited commentaries on 'Evolving to a new dominant logic for marketing", fournal of Marketing, Vol. 68 No. 1, pp. 18-27.

Deshpandé, R. and Farley, J.U. (1998), "Measuring market orientation: generalization and synthesis", fournal of MarketFocused Management, Vol. 2 No. 3, pp. 213-232.

Deshpande, R. and Webster, F. (1989), "Organizational culture and marketing: defining the research agenda", fournal of Marketing, Vol. 53 No. 1, pp. 3-15.

Dess, G.G. and Robinson, R.B. (1984), "Measuring organizational performance in the absence of objective measures: the case of the privately-held firm and conglomerate business unit", Strategic Management fournal, Vol. 5 No. 3, pp. 265-273.

Elbanna, S. (2015), "Intuition in project management and missing links: analyzing the predicating effects of environment and the mediating role of reflexivity", International Fournal of Project Management, Vol. 33 No. 6, pp. 1236-1248. 
Elbanna, S. (2016), “Managers' autonomy, strategic control, organizational politics and strategic planning effectiveness: an empirical investigation into missing links in the hotel sector", Tourism Management, Vol. 52, February, pp. 210-220.

Fadol, Y., Barhem, B. and Elbanna, S. (2015), "The mediating role of the extensiveness of strategic planning on the relationship between slack resources and organizational performance", Management Decision, Vol. 53 No. 5, pp. 1023-1044.

Fornell, C. and Larcker, D. (1981), "Evaluating structural equation models with unobservable variables and measurement error", fournal of Marketing Research, Vol. 18 No. 1, pp. 39-50.

Gallen, T. (2006), "Managers and strategic decisions: does the cognitive style matter?", Fournal of Management Development, Vol. 25 No. 2, pp. 118-133.

Goodenough, W. (1971), Culture, Language and Society, Addison Wesley, Reading, MA.

Gray, D. (2009), "The effect of managerial cognition and persistence on marketing team performance", Australian New Zealand Marketing Academy Annual Conference (ANZMAC), December 2009, Melbourne, pp. 1-9.

Gronroos, C. (1990), "Relationship approach to marketing in service contexts: the marketing and organizational behavior interface", Fournal of Business Research, Vol. 20 No. 1, pp. 3-11.

Grönroos, C. (1991), "The marketing strategy continuum: towards a marketing concept for the 1990s", Management Decision, Vol. 29 No. 1.

Grönroos, C. (1995), "Relationship marketing: the strategy continuum", fournal of the Academy of Marketing Science, Vol. 23 No. 4, pp. 252-254.

Gummesson, E. (2002), "Relationship marketing in the new economy", Fournal of Relationship Marketing, Vol. 1 No. 1, pp. 37-57.

Gummesson, E. (2004), "Return on relationships (ROR): the value of relationship marketing and CRM in business-to business contexts", Fournal of Business \& Industrial Marketing, Vol. 19 No. 2, pp. 136-148.

Hahn, C., Johnson, M.D., Herrmann, A. and Huber, F. (2002), "Capturing customer heterogeneity using a finite mixture PLS approach", Schmalenbach Business Review, Vol. 54 No. 3, pp. 243-269.

Hair, J., Ringle, C. and Sarstedt, M. (2011), "PLS-SEM: indeed a silver bullet", fournal of Marketing Theory and Practice, Vol. 19 No. 2, pp. 139-152.

Hair, J., Anderson, R., Tatham, R. and William, C. (2006), Multivariate Data Analysis, Prentice Hall, Upper Saddle River, NJ.

Håkansson, H. and Snehota, I. (1989), "No business is an island: the network concept of business strategy", Scandinavian Fournal of Management, Vol. 5 No. 3, pp. 187-200.

Hambrick, D. and Mason, P. (1984), "Upper echelons: the organization as a reflection of its top managers", Academy of Management Review, No. 2, pp. 193-206.

Hannan, M.T. and Freeman, J. (1977), "The population ecology of organizations", American fournal of Sociology, Vol. 82 No. 5, pp. 929-964.

Henseler, J., Ringle, C. and Sinkovics, R. (2009), "The use of partial least squares path modeling in international marketing", Advances in International Marketing, Vol. 20 No. 1, pp. 277-319.
Homburg, C. and Pflesser, C. (2000), “A multiple-layer model of market-oriented organizational culture: measurement issues and performance outcomes", fournal of Marketing Research, Vol. 37 No. 4, pp. 449-462.

Ivanova-Gongne, M. (2015), "Culture in business relationship interaction: an individual perspective”, Fournal of Business $\mathbb{E}$ Industrial Marketing, Vol. 30 No. 5, pp. 608-615.

Kaplan, S. (2011), "Research in cognition and strategy: reflections on two decades of progress and a look to the future", fournal of Management Studies, Vol. 48 No. 3, pp. 665-695.

Krepapa, A. and Berthon, P. (2003), "Making meaning interpretive diversity and market learning-a model and propositions", Management Theory, Vol. 3 No. 2, pp. 187-208.

Lindgreen, A., Palmer, R., Wetzels, M. and Antioco, M. (2008), "Do different marketing practices require different leadership styles? An exploratory study", Fournal of Business E Industrial Marketing, Vol. 24 No. 1, pp. 14-26.

Low, B., Tang, Y., Wang, P. and Zhang, Y. (2007), "Marketing and business performance of construction SMEs in China", fournal of Business E Industrial Marketing, Vol. 22 No. 2, pp. 118-125.

Lowe, S., Lowe, S., Rod, M., Rod, M., Hwang, K.-S. and Hwang, K.-S. (2016), "Understanding structures and practices of meaning-making in industrial networks", fournal of Business E Industrial Marketing, Vol. 31 No. 4, pp. 531-542.

Matsuno, K., Mentzer, J.T. and Özsomer, A. (2002), "The effects of entrepreneurial proclivity and market orientation on business performance", fournal of Marketing, Vol. 66 No. 3, pp. 18-32.

Miller, D. and Toulouse, J. (1982), "Top executive locus of control and its relationship to strategy-making, structure, and environment", Academy of Management fournal, Vol. 25 No. 2, pp. 237-253.

Özleblebici, Z., Pinto, C. and Antonio, N. (2015), "Variations in strategy perception among business and military managers", International fournal of Research in Business and Social Science, , Vol. 4 No. 1, pp. 17-31.

Pels, J. (2010), "How do managers understand the environment and how does it relate to the choice of a marketing practice?", $\mathrm{PhD}$, University of Leicester.

Pels, J., Moller, K. and Saren, M. (2009), "Do we really understand business marketing? Getting beyond the RM and BM matrimony", fournal of Business \& Industrial Marketing, Vol. 24 Nos 5/6, pp. 322-336.

Prahalad, C. and Bettis, R. (1986), "The dominant logic: a new linkage between diversity and performance", Strategic Management fournal, Vol. 7 No. 6, pp. 485-501.

Raskovic, M. (2015), "Economic sociology and the ARA interaction model", fournal of Business \& Industrial Marketing, Vol. 30 No. 5, pp. 472-485.

Ringle, C., Wende, S. and Will, A. (2005), SmartPLS 2.0 (M3) Beta.

Ryynänen, H., Henttonen, K. and Salminen, R.T. (2015), "Inter-organizational cognitive structures: network conception in MobileTV case", Fournal of Business $\mathcal{E}$ Industrial Marketing, Vol. 30 No. 5, pp. 662-676.

Sarstedt, M., Henseler, J. and Christian, M. (2011), "Multigroup analysis in partial least squares (PLS) path modeling: alternative methods and empirical results", Advances in International Marketing, Vol. 22 No. 1, pp. 195-218. 
Schneider, S. and Shrivastaval, P. (1988), "Basic assumptions themes in organizations", Human Relations, Vol. 41 No. 7, pp. 493-515.

Sheth, J. (2011), "Impact of emerging markets on marketing: rethinking existing perspectives and practices", fournal of Marketing, Vol. 75 No. 4, pp. 166-182.

Sheth, J. and Parvatiyar, A. (2000), Handbook of Relationship Marketing, Sage Publications, Thousand Oaks, CA.

Shrivastava, P. and Mitroff, I. (1983), "Frame of reference managers use", Advances in Strategic Management, Vol. 1, pp. 161-182.

Shrivastava, P. and Mitroff, I. (1984), "Enhancing organizational research utilization: the role of decision makers' assumptions", Academy of Management Review, Vol. 9 No. 1, pp. 18-26.

Souiden, N. (2002), "Segmenting the Arab markets on the basis of marketing stimuli", International Marketing Review, Vol. 19 No. 6, pp. 611-636.

Sweeney, J.C., Soutar, G.N. and McColl-Kennedy, J.R. (2011), "The marketing practices-performance relationship in professional service firms", fournal of Service Management, Vol. 22 No. 3, pp. 292-316.

Thomas, A.S. and Ramaswamy, K. (2005), "Matching managers to strategy: further tests of the miles and snow typology", British foumal of Management, Vol. 7 No. 3, pp. 247-261.

Tollin, K. and Jones, R. (2009), "Marketing logics for competitive advantage?", European fournal of Marketing, Vol. 43 Nos 3/4, pp. 523-550.
Tuncalp, S. (1999), "Evaluation of information sources in industrial marketing: implications for media planning in the Arabian Gulf", Fournal of Business E Industrial Marketing, Vol. 14 No. 1, pp. 49-60.

Vargo, S. and Lusch, R. (2004), "Evolving to a new dominant logic for marketing", fournal of Marketing, Vol. 68 No. 1, pp. 1-17.

Wagner, R. (2005), "Contemporary marketing practices in Russia”, European fournal of Marketing, Vol. 39 Nos 1/2, pp. 199-215.

Walsh, J.P. (1995), "Managerial and organizational cognition: notes from a trip down memory lane”, Organization Science, Vol. 6 No. 3, pp. 280-321.

Webster, F. (2005), "Back to the future: integrating marketing as tactics, strategy, and organizational culture", fournal of Marketing, Vol. 69 No. 4, pp. 1-25.

White, J., Varadarajan, P. and Dacin, P. (2003), "Market situation interpretation and response: the role of cognitive style, organizational culture, and information use", fournal of Marketing, Vol. 67 No. 3, pp. 63-79.

Wilson, B. (2010), "Using PLS to investigate interaction effects between higher order branding constructs", Handbook of Partial Least Squares, Springer.

Zahlan, R. (2016), The Making of the Modern Gulf States: Kuwait, Bahrain, Qatar, the United Arab Emirates and Oman, Routledge, Abingdon.

Zhao, X., Huo, B., Selen, W. and Yeung, J.H.Y. (2011), "The impact of internal integration and relationship commitment on external integration", fournal of Operations Management, Vol. 29 Nos 1/2, pp. 17-32. 


\section{Appendix. Questionnaire}

SECTION 1 - ABOUT MARKETING PRACTICES WITH YOUR PRIMARY CUSTOMERS. This section has a number of questions about how marketing is practiced in your firm with your "PRIMARY customers", For each question, please read all parts. Then please answer all parts of each question by circling the number on each scale that best corresponds to what actually happens in your firm.

\begin{tabular}{|c|c|c|c|c|c|c|c|}
\hline & Our marketing activities are intended to: & \multicolumn{3}{|c|}{ Never } & \multicolumn{2}{|c|}{ always } & NA \\
\hline & attract new customers & 1 & 2 & 3 & 4 & 5 & 6 \\
\hline b) & retain existing customers & 1 & 2 & 3 & 4 & & 6 \\
\hline c) & develop cooperative relationships with our customers & 1 & 2 & 3 & 4 & & 6 \\
\hline d) & $\begin{array}{l}\text { coordinate activities between ourselves, customers, and } \\
\text { other parties in our wider marketing system (e.g. key } \\
\text { suppliers, service providers and other organisations with } \\
\text { which we interact) }\end{array}$ & 1 & 2 & 3 & 4 & & 6 \\
\hline
\end{tabular}

\begin{tabular}{|l|ll|l|}
\hline 2) Our Marketing planning is focused on issues related & Never & always & NA \\
\hline
\end{tabular}

\begin{tabular}{|c|c|c|c|c|c|c|}
\hline a) our product/brand/service offering & 1 & & 3 & & & \\
\hline b) customers in our market(s) in addition to our offer & 1 & 2 & 3 & 4 & 5 & 6 \\
\hline $\begin{array}{l}\text { c) one-to-one relationships with customers in our market(s), } \\
\text { or individuals in organisations we deal with }\end{array}$ & 1 & 2 & 3 & 4 & 5 & 6 \\
\hline $\begin{array}{l}\text { e) the network of relationships between individuals and } \\
\text { organisations in our wider marketing system }\end{array}$ & 1 & 2 & 3 & 4 & 5 & 6 \\
\hline
\end{tabular}

\begin{tabular}{|c|c|c|c|c|c|}
\hline 3) When dealing with our market(s), our purpose is to: & Never & & alway & & NA \\
\hline $\begin{array}{l}\text { a) generate a profit or other "financial" measure(s) of } \\
\text { performance (monetary transaction) }\end{array}$ & 1 & 2 & 4 & 5 & 6 \\
\hline $\begin{array}{l}\text { b) acquire customer information for our database in addition } \\
\text { to financial/monetary transactions }\end{array}$ & 1 & 2 & 4 & 5 & 6 \\
\hline c) build a long-term relationship with a specific customer(s) & 1 & 2 & 4 & 5 & 6 \\
\hline $\begin{array}{l}\text { d) form relationships with a number of organisations in our } \\
\text { market(s) or wider marketing system }\end{array}$ & 1 & 2 & 4 & 5 & 6 \\
\hline
\end{tabular}

\begin{tabular}{|l|llllll|l|}
\hline 4) $\begin{array}{l}\text { Our organisation's contact with our primary } \\
\text { customers is: }\end{array}$ & Never & & always & NA \\
\hline a) & $\begin{array}{l}\text { arms-length, impersonal with no individualised or } \\
\text { personal contact }\end{array}$ & $\mathbf{1}$ & $\mathbf{2}$ & $\mathbf{3}$ & $\mathbf{4}$ & $\mathbf{5}$ & $\mathbf{6}$ \\
\hline b) & somewhat personalised (e.g. by direct mail) & $\mathbf{1}$ & 2 & $\mathbf{3}$ & $\mathbf{4}$ & $\mathbf{5}$ & $\mathbf{6}$ \\
\hline c) interpersonal (e.g. involving one-to-one interaction) & $\mathbf{1}$ & $\mathbf{2}$ & $\mathbf{3}$ & $\mathbf{4}$ & $\mathbf{5}$ & $\mathbf{6}$ \\
\hline d) & $\begin{array}{l}\text { from impersonal to interpersonal across firms in the } \\
\text { broader network }\end{array}$ & $\mathbf{1}$ & $\mathbf{2}$ & $\mathbf{3}$ & $\mathbf{4}$ & $\mathbf{5}$ & $\mathbf{6}$ \\
\hline
\end{tabular}

d) from impersonal to interpersonal across firms in the

\section{5) The type of relationship with our customers is} haracterised as:

a) transactions that are discrete or one-o

b) contact (e.g. by direct mail) that is occasional

c) interpersonal interaction that is ongoing

d) contact with people in our organisation and wider

markenin

\begin{tabular}{|l|l|l|}
\hline 6) Our marketing resources (i.e. people, time and & Never always & NA
\end{tabular}

product, promotion, price, and distribution activities (or

product, promotion, $\mathrm{p}$
some combination of

customers

establishing and building personal relationships with

individual customers

network relationship

within our market(s) or wider marketing system

7) In our organisation, marketing activities are carried out by:

sales manager, major account manager

b) specialist marketers (e.g. customer service manager,

c) many employees (across functions and levels)

d) the Managing Director or $\mathrm{CEO}$

\begin{tabular}{|lllll|l|}
\hline Never & \multicolumn{3}{|l|}{ always } & NA \\
\hline 1 & 2 & 3 & 4 & 5 & 6 \\
1 & 2 & 3 & 4 & 5 & 6 \\
1 & 2 & 3 & 4 & 5 & 6 \\
1 & 2 & 3 & 4 & 5 & 6
\end{tabular}

\begin{tabular}{|c|c|c|c|c|c|}
\hline 8) Our marketing communication involves: & Never & & & & NA \\
\hline a) our organisation communicating to the mass market & 1 & 3 & 4 & 5 & 6 \\
\hline $\begin{array}{l}\text { b) our organisation targeting a specifically identified } \\
\text { segment(s) or customer(s) }\end{array}$ & 1 & 3 & 4 & 5 & 6 \\
\hline $\begin{array}{l}\text { individuals at various levels in our organisation } \\
\text { personally interacting with their individual customers }\end{array}$ & 1 & 3 & 4 & 5 & 6 \\
\hline $\begin{array}{l}\text { d) senior managers networking with other managers from a } \\
\text { variety of organisations in our market(s) or wider } \\
\text { marketing system }\end{array}$ & 1 & 3 & 4 & 5 & 6 \\
\hline
\end{tabular}

(continued)

\begin{tabular}{|c|c|c|c|c|c|c|}
\hline $\begin{array}{l}\text { 9) When people from our organisation meet with our } \\
\text { primary customers, it is: }\end{array}$ & Never & & & & & $\overline{\mathrm{NA}}$ \\
\hline a) mainly at a formal level & 1 & 2 & 3 & 4 & 5 & 6 \\
\hline $\begin{array}{l}\text { b) mainly at a formal level, yet personalised via database } \\
\text { technologies }\end{array}$ & 1 & 2 & 3 & 4 & 5 & 6 \\
\hline $\begin{array}{l}\text { c) at both a formal business level and informal social level } \\
\text { on a one-to-one basis }\end{array}$ & $\begin{array}{llll}1 & & & \\
\end{array}$ & 2 & 3 & 4 & 5 & 6 \\
\hline $\begin{array}{l}\text { d) at both a formal business level and informal social level in } \\
\text { a wider organisational system/network }\end{array}$ & 1 & 2 & 3 & 4 & 5 & 6 \\
\hline
\end{tabular}

Section 2: Listed below are a series of general statements about your Management style. Please circle the number which best describes your opinion

\begin{tabular}{|c|c|c|c|c|c|c|}
\hline & $\begin{array}{l}\text { how valuable or important do you usually find these } \\
\text { information sources to be in providing you with } \\
\text { information with which to make decisions: }\end{array}$ & Never & & & & NA \\
\hline a) & Subjective personal experience (Qualitative data ) & 1 & 3 & & 5 & 6 \\
\hline & $\begin{array}{l}\text { Quantitative, numerical, Objective data ( files, formal } \\
\text { reports) }\end{array}$ & 1 & 3 & & 5 & 6 \\
\hline
\end{tabular}

\begin{tabular}{|l|l|l|l|}
\hline 2) How frequently, do you obtain information for & Never & always & NA \\
\hline
\end{tabular}

\begin{tabular}{|l|llllll|l|l|}
\hline $\begin{array}{l}\text { decision making from the following sources: } \\
\text { c) subordinates, peers, friends }\end{array}$ & $\mathbf{1}$ & $\mathbf{2}$ & $\mathbf{3}$ & $\mathbf{4}$ & $\mathbf{5}$ & 6
\end{tabular}

\begin{tabular}{ll|lllll|l|l|l} 
d) reports, documents and files, including handbooks, & 1 & 2 & 3 & 4 & 5 & 6
\end{tabular}

\begin{tabular}{|l|l|l|} 
procedures, memos, and newsletters; & & \\
\hline
\end{tabular}

\begin{tabular}{|l|l|l|l|}
\hline 3) How often do you use the following sources to obtain & Never & always & NA \\
\hline
\end{tabular}

\begin{tabular}{|l|lllll|l|}
\hline & information for decision making & & & & & \\
\hline a) Company internal sources ( Employees, firm report, etc) & 1 & 2 & 3 & 4 & 5 & 6 \\
\hline b) external sources ( research agencies, government, & 1 & 2 & 3 & 4 & 5 & 6
\end{tabular}

\begin{tabular}{|l|ll|l|} 
4) When solving a business issues my goal or objectives & Never & always & NA \\
\hline
\end{tabular}

Wien solving a basiness issues ing gonlor objectives

is to increase the gain of :
a) Personal goals (e.g. financial, career, etc)

\begin{tabular}{|l|llllll|l|l|} 
c) My friends, family or even my country people & 1 & 2 & 3 & 4 & 5 & 6 \\
\hline
\end{tabular}

\begin{tabular}{|c|c|c|c|c|c|}
\hline 5) When making decisions, I tend to rely on & Never & & & & $\mathrm{NA}$ \\
\hline $\begin{array}{l}\text { a) My instincts and beliefs with nonstandard procedures. } \\
\text {. }\end{array}$ & 1 & 3 & 4 & 5 & 6 \\
\hline b) I make decisions in a logical and systematic way & 1 & 3 & 4 & 5 & 6 \\
\hline dvise and suggestion from friends and colleagues & 2 & 3 & 4 & 5 & 6 \\
\hline
\end{tabular}

\begin{tabular}{|c|c|c|c|c|c|}
\hline $\begin{array}{l}\text { When faced with a problem, I tend to define this } \\
\text { problem using : }\end{array}$ & Never & & & & NA \\
\hline a) intuitive images based on my previous experience & 2 & 3 & 4 & 5 & 6 \\
\hline $\begin{array}{l}\text { b) using analytical models, structured categorical schemes, } \\
\text { scientific Theories }\end{array}$ & 1 & 3 & 4 & 5 & 6 \\
\hline
\end{tabular}

\begin{tabular}{|l|llllll|l|}
\hline 7) $\begin{array}{l}\text { In formulating the problem or making a decision to } \\
\text { solve it, my analysis and decision tend to be : }\end{array}$ & \multicolumn{1}{l}{ Never } & & always & NA \\
\hline a) Limited analysis, with solutions of short term perspective. & $\mathbf{1}$ & $\mathbf{2}$ & $\mathbf{3}$ & $\mathbf{4}$ & $\mathbf{5}$ & $\mathbf{6}$ \\
\hline $\begin{array}{l}\text { b) Long range analysis, and solutions tend to be long run } \\
\text { solutions }\end{array}$ & $\mathbf{1}$ & $\mathbf{2}$ & 3 & $\mathbf{4}$ & $\mathbf{5}$ & $\mathbf{6}$ \\
\hline c) Interpersonal problem inquiry and analysis & $\mathbf{1}$ & $\mathbf{2}$ & $\mathbf{3}$ & $\mathbf{4}$ & $\mathbf{5}$ & $\mathbf{6}$ \\
\hline
\end{tabular}

\begin{tabular}{|l|l|l|l|}
\hline 8) The test I use to determine the realness of firm & Never & always & NA \\
\hline
\end{tabular}

\begin{tabular}{|l|llllll|l|}
\hline $\begin{array}{c}\text { problem or information is : } \\
\text { a) My previous experience }\end{array}$ & $\mathbf{1}$ & $\mathbf{2}$ & $\mathbf{3}$ & $\mathbf{4}$ & $\mathbf{5}$ & $\mathbf{6}$
\end{tabular}

\begin{tabular}{|l|llllll|l|}
\hline b) Firmal rules and procedures & 1 & 2 & 3 & 4 & 5 & 6 \\
\hline
\end{tabular}

\begin{tabular}{|l|llllll|l|l|} 
c) Empirical experimental proofs (such as data) & 1 & 2 & 3 & 4 & 5 & 6 \\
\hline
\end{tabular}

\begin{tabular}{|l|llllll|l} 
d) Popular wisdom (social and firmal norms) & 1 & 2 & 3 & 4 & 5 & 6 \\
\hline
\end{tabular}

\begin{tabular}{|l|ll|l|}
\hline 9) While inquiring for information to solve a business & Never & always & NA \\
\hline
\end{tabular}

\begin{tabular}{|l|lllllll|l|}
\hline \multicolumn{2}{c}{ problem, the boundaries of my inquiry : } & & & & & & & \\
\hline a) Changes Continuously & 1 & 2 & 3 & 4 & 5 & 6 \\
\hline
\end{tabular}

\begin{tabular}{|l|lllllll|l|} 
c) Changes with the interest of the top manager & 1 & 2 & 3 & 4 & 5 & 6
\end{tabular}

\begin{tabular}{|l|ll|l|}
\hline 10) While inquiring for information to solve a business & Never & always & NA \\
\hline
\end{tabular}

\begin{tabular}{|l|llllll|l|l|}
\hline \multicolumn{2}{c|}{ problem, the boundaries of my inquiry are : } & & & & & & \\
\hline a) Narrow (problem itself) & 1 & 2 & 3 & 4 & 5 & 6 \\
\hline
\end{tabular}

\begin{tabular}{|l|lllll|l} 
b) Department or division & 1 & 2 & 3 & 4 & 5 & 6
\end{tabular}

c) Firm

d) Broad (firm and general economy) 


\begin{tabular}{|c|c|c|c|c|c|}
\hline \multirow[b]{2}{*}{ 1) My firm sales growth compared to industry average } & \multicolumn{3}{|c|}{ Much worse } & \multicolumn{2}{|c|}{ Much better } \\
\hline & 1 & 2 & 3 & 4 & 5 \\
\hline 2) My Firm Market share compared to industry average & 1 & 2 & 3 & 4 & 5 \\
\hline 3) My firm Profitability compared to industry average. & 1 & 2 & 3 & 4 & 5 \\
\hline 4) My firm Sales growth compared to business unit objectives. & 1 & 2 & 3 & 4 & 5 \\
\hline 5) My firm Market share compared to business unit objectives. & 1 & 2 & 3 & 4 & 5 \\
\hline 6) My firm Profitability compared to business unit obj & 1 & 2 & 3 & 4 & 5 \\
\hline
\end{tabular}

SECTION 4: In this section we ask you for details about your firm. By "your firm" we mean the legally constituted entity where you are employed.

1. When was your firm established?

a) Less than 2 years ago

b) 3-5 years ago

d) $11-30$ years ago

More than 30 years ago

2. How many people are currently:

a) Employed in the firm you work for?
b) And of those, how many are employed in marketing activities (excluding sales)?

c) How many are employed in sales activities (excluding marketing)?

3. Please tick the category that best describes the markets your firm serves:

a) Consumer
b) Business

c) Both

4. Is your firm?

b) Foreign Own

5. Please tick the category that best describes your firm's line of business (market offer) a) Goods

b) Services
c) Both

SECTION 5: The following are background questions. The survey is incomplete unless they are

answered. Please circle the one which best describes you.

1. The nature of my current position is:

a) Upper management

b) Middle management

c) Low level Management

2. Area of expertise or specialization

a) Marketing and sales

b) Finance and accounting

c) Human resource

d) Engineering

e) Other

3. Highest degree of education

a) Some high school

High school diplo
Some college

Some college

e) Graduate degree

4. Years of experience

a) Less than 3 Years

b) $3-5$ years

10 years or more

5. My age

a) $18-30$

$41-50$

My gender

My gender

b) Female

\section{About the authors}

Allam Abu Farha is an Assistant Professor at Qatar University. In addition to his academic career, he served as a Marketing Consultant for several firms in Canada and the Middle East. His research interests include marketing practices of emerging economies, managerial cognition and consumer behavior. He is involved in several multinational research projects and has presented at numerous international conferences and has published in a number of international academic journals. Allam Abu Farha is the corresponding author and can be contacted at: afarha@qu.edu.qa

Said Elbanna is a Professor at Qatar University. His research interests are in the areas of decision-making, strategic planning and internationalization of SMEs. He has published in journals, such as Strategic Management fournal, Long Range Planning, Tourism Management and Public Management Review. $\mathrm{He}$ has received several research awards, including the JMS Best Paper Award for 2007.

For instructions on how to order reprints of this article, please visit our website:

www.emeraldgrouppublishing.com/licensing/reprints.htm

Or contact us for further details: permissions@emeraldinsight.com 